\title{
Meningkatkan Hasil Belajar Tema Diri Sendiri Materi mengenal geometri dengan Media Keping Geometri pada Kelompok A TK Islam An - Nur Beber Kec. Jonggat Tahun Pelajaran 2018 / 2019
}

\author{
Saimah \\ Guru TK Islam An-Nur Beber Kec. Jonggat Lombok Tengah
}

\begin{abstract}
Abstrak. Jenis penelitian ini adalah penelitian tindakan kelas dengan subjek penelitian siswa Usia A TK Islam An-Nur Beber Kecamatan Jonggat Kabupaten lombok Tengah. Penelitian ini dilaksanakan pada bulan Juli Sampai dengan September 2018, dengan jumlah sampel sebanyak 20 siswa terdiri dari 7 siswa laki - laki dan 13 siswa perempuan dan model penelitian yang digunakan model Kemmis dan Mc Tanggar Jika melihat perbandingan kedua data tersebut maka dapat kita paparkan bahwa nilai rata - rata yang diperoleh pada siklus I sebesar 66,7 kemudian meningkat pada siklus I I menjadi nilai rata - rata diperoleh sebesar 85,7 terjadi peningkatan 19 poin, dan jumlah siswa yang tuntas pada siklus I sebanyak 11 orang atau dengan persentase ketuntasan sebesar 55\%, kemudian meningkat pada siklus II jumlah siswa yang tuntas sebanyak 19 orang dengan persentase sebesar $95 \%$, terjadi peningkatan sebesar 40 poin, begitu juga dengan ketuntasan klasikal yang dipersyaratkan $\geq 80 \%$ juga sudah terpenuhi, maka penelitian ini dihentikan sampai pada siklus II. Dengan demikian dapat diambil kesimpulan bahwa dengan menggunakan media keping Geometri dapat meningkatkan hasil belajar siswa tema Diri sendiri materi mengenal geometri pada Kelompok A TK Islam An-Nur Beber Kecamatan Jonggat Tahun pelajaran 2018 / 2020.
\end{abstract}

\section{Kata Kunci: Hasil Belajar, Media Pembelajaran, Keping Geometri}

\section{PENDAHULUAN}

\section{Latar Belakang Masalah}

Undang-Undang Nomor 20 Tahun

2003 tentang Sistem Pendidikan Nasional, secara tegas menyatakan bahwa "Pendidikan anak usia dini adalah suatu upaya pembinaan yang ditujukan kepada anak sejak lahir sampai dengan usia enam tahun yang dilakukan melalui pemberian rangsangan pendidikan untuk membantu pertumbuhan dan perkembangan jasmani dan rohani agar anak memiliki kesiapan dalam memasuki pendidikan lanjut". Selanjutnya dinyatakan pula bahwa pendidikan anak usia dini dapat diselenggarakan pada jalur formal (Taman Kanak-kanak/ Raudhathul Athfal), jalur nonformal (Taman Penitipan Anak, Kelompok Bermain, dan bentuk lain yang sederajat), dan pada jalur informal (melalui pendidikan keluarga atau lingkungan).

Pendidikan merupakan suatu hubungan yang terjadi antara pendidik (guru) dan siswa. Melalui pendidikan siswa dipersiapkan menjadi manusia yang cerdas dan berguna bagi nusa dan bangsa, serta diharapkan dapat mengembangkan potensinya untuk menjadi lebih baik. Dalam upaya menumbuhkan, memajukan, serta mencerdaskan kehidupan bangsa penyelenggaraan dan pelaksanaan proses pendidikan harus terus ditingkatkan.

$$
\text { Proses pendidikan berarti }
$$
didalamnya menyangkut kegiatan belajar mengajar dengan segala aspek maupun faktor yang mempengaruhinya. Pada hakekatnya, untuk menunjang tercapainya tujuan pengajaran, perhatian siswa pada saat proses belajar mengajar merupakan pencerminan kegiatan belajar mengajar yang melibatkan siswa, guru, materi pelajaran, metode pengajaran, sarana atau fasilitas belajar, kurikulum yang sesuai dengan kebutuhan siswa dan didukung oleh lingkungan yang mendukung kegiatan belajar mengajar. Pekerjaan mengajar tidak selalu harus diartikan sebagai kegiatan menyajikan materi pelajaran. Meskipun penyajian materi pelajaran memang merupakan bagian dari kegiatan pembelajaran, tetapi bukanlah satusatunya. Masih banyak cara lain yang dapat 
dilakukan guru untuk membuat siswa belajar. Peran yang seharusnya dilakukan guru adalah mengusahakan agar setiap siswa dapat berinteraksi secara aktif dengan berbagai sumber balajar yang ada.

Proses belajar mengajar, terdapat beberapa faktor yang dapat menghambat aktifitas dan prestasi belajar peserta didik, sehingga prestasi dan aktifitas belajar siswa menurun. Prestasi belajar dipengaruhi oleh banyak faktor yang digolongkan menjadi dua faktor, yaitu faktor internal dan faktor eksternal. Faktor internal merupakan faktor yang berasal dari dalam diri siswa seperti minat, motivasi, sikap, kesehatan, tingkat intelegensi dan kebiasaan belajar, sedangkan faktor eksternal adalah faktor yang berasal dari luar diri siswa seperti keluarga, metode belajar di sekolah, fasilitas belajar, disiplin sekolah, guru dan masyarakat.

Menurut Conny Semiawan yang dikutip oleh W. Gulo (2002: 76-77) prinsipprinsip yang perlu diperhatikan dalam menciptakan kondisi belajar yang mengoptimalkan aktivitas siswa dalam belajar, antara lain: prinsip motivasi, prinsip latar atau konteks yaitu prinsip keterhubungan bahan baru dengan apa yang telah diperoleh siswa sebelumnya, prinsip perbedaan perorangan, prinsip menemukan, dan prinsip memecahkan masalah. Prinsip pemecahan masalah (problem solving) berarti mengarahkan siswa untuk lebih peka pada masalah dan mempunyai ketrampilan untuk menyelesaikannya.

Belajar adalah suatu proses usaha yang dilakukan seseorang untuk memperoleh suatu perubahan tingkah laku yang baru secara keseluruhan, sebagai hasil pengalamannya sendiri dalam interaksi dengan lingkungannya (Slameto, 2010: 2). Berdasarkan hal tersebut, maka aktivitas yang terjadi di dalam pembelajaran sebaiknya didominasi oleh aktivitas mengkonstruksi pengetahuan secara mandiri oleh siswa.

$$
\text { Cara menguasai materi }
$$

Mencocokkan gambar pada tema lingunganku masih banyak yang cenderung didominasi aktivitas guru sehingga siswa kurang aktif merekonstruksi pengetahuannya sendiri sehingga siswa kelihatan tidak antosias dalam proses belajar mengajar. Pembelajaran Tema diriku di TK Islam An - Nur Beber masih bersifat konvensional, yakni guru menyampaikan materi pembelajaran sedangkan siswa hanya mengikuti secara pasif di tempat duduk masing- masing. Komunikasi yang terjadi cenderung satu arah dan monoton yaitu guru menerangkan, memberi contoh, sesekali memberi pertanyaan, tetapi kurang memotivasi siswa untuk aktif memahami, dan kemudian guru memberi latihan soal dan kadang-kadang dijadikan PR. Sementara itu siswa duduk mendengarkan penjelasan guru, serta mengerjakan soal-soal yang diberikan guru apabila guru memeriksa pekerjaan siswa dengan berkeliling kelas, sehingga siswa menjadi pasif mengikuti pembelajaran dan memiliki ketergantungan yang besar pada guru.

Berdasarkan hasil ulangan harian dilakukan pada tema lingkunganku menunjukkan bahwa hasil belajar kelompok bermain A khususnya pada materi mengenal geometri masih rendah dari 20 siswa yang tuntas belajar hanya 5 orang atau persentase sebesar $25 \%$ dan siswa yang belum tuntas sebanyak 15 siswa atau persentase sebesar 75 $\%$ sedangkan KKM yang ditetapkan di TK Islam An-nur Beber adalah 65 untuk tahun pelajaran 2018 / 2019 sehingga, masih diperlukan suatu perbaikan, hal ini desebabkan karena siswa tidak tertarik pada pelajaran sehingga menjadi kurang aktif dalam kegiatan belajar mengajar,

Melihat permasalahan di atas, terdapat suatu gambaran bahwa akar penyebab masalah pada Media pembelajaran yang kurang menarik sehingga anak kurang mampu membangkitkan keterampilan berpikir kritis siswa, sehingga sebagian siswa khususnya Kelompok Bermain A TK Islam An-nur Beber kurang tertarik yang berdampak pada hasil belajar yang rendah .

Bertolak dari permasalahan yang dijumpai di kelas diupayakan dengan suatu tindakan guru untuk mengatasi permasalahan pembelajaran untuk meningkatkan keterampilan siswa pada tema lingkunganku. Dengan permasalahan rendahnya prestasi atau hasil belajar siswa tersebut beberapa upaya dilakukan salah satunya adalah dengan 
menggunakan media yang menarik yaitu Keping Geometri pembelajaran yang dapat membuat siswa tertarik dan menyenangkan ketika belajar.

$\begin{array}{crr} & \text { Dengan menggunakan } & \text { Keping } \\ \text { Geometri } & \text { secara optimal dalam }\end{array}$
pembelajaran diharapkan siswa akan lebih aktif dan kreatif dalam mengikuti pelajaran Tema Tanaman dengan materi Mengenal bentuk geometri

Atas dasar tersebut selaku guru TK Islam An-nur Beber tertarik melakukan penelitian dengan judul" Meningkatkan Hasil Belajar Tema Diri Sendiri Materi Geometri dengan Keping Geometri pada kelompok Bermain A TK Islam An-nur Beber Tahun Pelajaran 2018 /2019"

\section{Rumusan Masalah}

Berdasarkan permaslahan tersebut diatas peneliti merumuskan masalah " Bagaimanakah Meningkatkan Hasil Belajar Tema Diri Sendiri Materi Geometri dengan Keping Geometri pada kelompok Bermain A TK Islam An-nur Beber Tahun Pelajaran 2018 /2019"

\section{Tujuan Penelitian}

Tujuan dari penelitian ini adalah:" Meningkatkan Hasil Belajar Tema Diri Sendiri Materi Geometri dengan Keping Geometri pada kelompok Bermain A TK Islam An-nur Beber Tahun Pelajaran 2018 /2019"

\section{Manfaat Penelitian}

Penelitian ini diharapkan dapat memberikan manfaat secara teoritis maupun praktis: Secara teoritis penelitian ini memperkaya khasanah ilmu pendidikan yang berhubungan dengan penerapan metode pembelajaran yang tepat bagi peserta didik. Meningkatkan kreatifitas seorang pendidik dalam memberikan metode pembelajaran bagi peserta didiknya sehingga peserta didik dengan mudah menerima penjelasan dan pengetahuan yang diberikan oleh pendidik (guru). Secara praktis penelitian ini, dapat dijadikan referensi dan tambahan pengetahuan tentang pendekatan dan media pembelajaran yang baik seuai dengan materi yang akan di ajarkan.

\section{LANDASAN TEORI DAN KAJIAN}

\section{PUSTAKA \\ Pengertian belajar}

Belajar ialah suatu proses usaha yang dilakukan seseorang untuk memperoleh suatu perubahan tingkah laku yang baru secara keseluruhan, sebagai hasil pengalamannya sendiri dalam interaksi dengan lingkungannya (Slameto, 2010: 2). Belajar adalah setiap perubahan yang relatif menetap dalam tingkah laku yang terjadi sebagai suatu hasil dan latihan atau pengalaman (Ngalim Purwanto, 1993: 84).

Untuk mengetahui bahwa tidak semua perubahan yang terjadi pada manusia merupakan hasil belajar atau prestasi belajar. Perubahan yang dimaksud ini yaitu perubahan yang terjadi secara sadar dan tertuju untuk memperoleh sesuatu yang lebih baik dari sebelumnya, dengan demikian perubahan hasil belajar semakin banyak usaha yang dilakukan akan semakin baik perubahan yang akan dicapai.

\section{Pengertian Hasil belajar}

Menurut kamus besar bahasa Indonesia (Siti Nurjanah, 2007: 14), hasil belajar adalah penguasaan pengetahuan atau keterampilan yang dikembangkan oleh mata pelajaran, lazimnya ditunjukkan dengan nilai tes atau nilai yang diberikan kepuasan kepada individu yang belajar. Nana Sudjana (2002: 22) menyatakan bahwa hasil belajar merupakan kemampuan-kemampuan yang dimiliki setelah seseorang memiliki pengalaman belajarnya. Jadi dapat disimpulkan bahwa hasil belajar adalah kemampuan-kemampuan yang diperoleh siswa melalui kegiatan belajar. Siswa yang berhasil dalam belajar yaitu yang berhasil mencapai tujuan-tujuan pembelajaran.

Hasil belajar ditentukan oleh evaluasi. Evaluasi hasil belajar merupakan proses untuk menentukan nilai belajar siswa melalui kegiatan penilaian dan pengukuran hasil belajar. Tujuan utama evaluasi adalah untuk mengetahui tingkat keberhasilan yang dicapai siswa setelah mengikuti suatu kegiatan pembelajaran. Tingkat keberhasilan dapat dinyatakan dalam huruf, kata atau simbol (Dimyati Mudjiono, 2002: 200).

Faktor-faktor yang Mempengaruhi Proses dan Hasil Belajar 
Menurut Ngalim Purwanto (2000: 106), faktor-faktor yang mempengaruhi proses dan hasil belajar sebagai berikut:

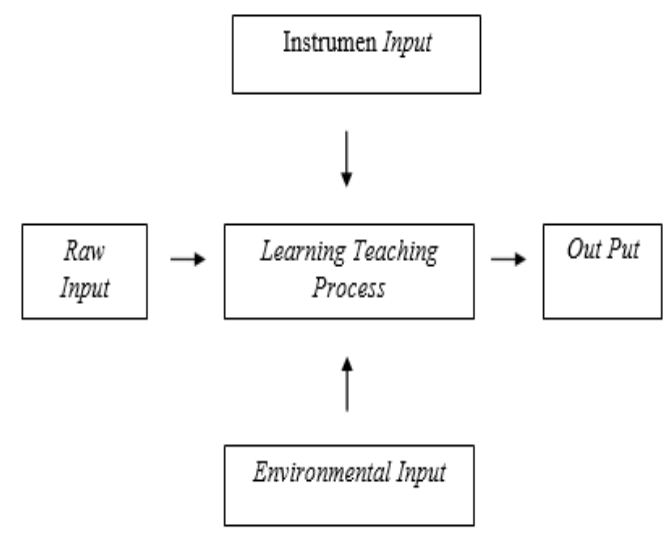

Gambar 1. Faktor-faktor yang Mempengaruhi Proses dan Hasil Belajar

Dari unsur-unsur tersebut diuraikan sebagai berikut; 1) Sebagai raw input adalah siswa, mereka diberi pengalaman tertentu dalam proses belajar mengajar, dengan tujuan dapat berubah menjadi out put (keluar) dengan kualitas tertentu, 2) Dalam proses belajar mengajar ikut berpengaruh juga faktor instrumental (Instrumental Input) dan juga faktor lingkungan program pengajaran/kurikulum, guru, sarana dan prasarana pembelajaran, sumber bahan pelajaran dan tenaga non pengajar. Faktor instrumental merupakan faktor yang dapat dimanipulasi atau dikondisikan sehingga sesuai denan kebutuhan siswa. Sedangkan factor lingkungan meliputi lingkungan alam sosial dan budaya. Faktor lingkungan ini pun harus disesuaikan dengan kebutuhan pembelajaran.

\section{Keping Geometri}

Alders (seperti yang di kutip Asmarani, 2014) Menyatakan bahwa geometri adalah salah satu cabang matematika yang mempelajari tentang titik, garis, bidang dan benda-benda ruang beserta sifat-sifatnya ukuran-ukuranya dan hubungan antara satu dengan yang lain. Setiawan (seperti yang di kutip Rifqi Fauzi, 2012) Suatu cabang matematika yang menerangkan sifat-sifat garis, sudut, bidang, dan ruang, dua ilmu ukur. Iswadji (seperti yang di kutip Rifqi Fauzi, 2012) Menyatakan bahwa Geometri adalah setiap bangun yang dipandang sebagai himpunan titik-titik tertentu (special set points), sedangkan ruang artinya sebagai himpunan semua titik. Dalam matematika bangun-bangun geometri merupakan bendabenda pikiran yang memiliki bentuk dan ukuran yang serba sempurna. Geometri merupakan bagian matematika yang sangat banyak kegunaannya dalam kehidupan seharihari.

Dari definisi diatas geometri dapat diartikan sebagai salah satu cabang dari ilmu matematika yang mempelajari tentang titik, garis, bangun datar, dan bangun ruang dan mempunyai ukuran. Manfaat Geometri Rahmawati (2014) menyatakan bahwa geometri bidang mempunyai manfaat dalam kehidupan sehari-hari sebagai beriktut: Bidang setengah bola digunakan arsitek untuk membuat jembatan Sudut digunakan untuk mengukur suatu gedung Diameter lingkaran digunakan untuk membuat roda agar seimbang Segitiga sama kaki digunakan untuk membuat atap rumah Bidang datar sebagai dasar pembuatan lantai Kubus sebagai dasar pembuatan kabah, Persegi panjang digunakan untuk membuat sejadah Aturan barisan berkaitan dengan garis lurus pada geometri

$$
\text { Jenis-jenis Geometri }
$$

Matematika materi geometri yang dipelajari di tiap sekolah terbagi menjadi dua hal yaitu bangun datar dan bangun ruang, adapun pengertian bangun datar dan bangun ruang adalah sebagai berikut: Bangun Datar Tarigan (seperti yang di kutip Fauzi, Ramdan, 2012) Benda-benda dilihat dengan mata telanjang terlihat rata atau datar belum tentu memenuhi syarat untuk digolongkan sebagai bangun datar, dengan demikian pengertian bangun datar adalah abstrak. Dari definisi sebelumnya bangun datar bisa diartikan sebagai bagian dari materi geometri berupa suatu gambar yang terbentuk dari perpotongan kurva atau garis sehingga gambar tersebut tidak memiliki ketebalan menjadikannya hanya memiliki keliling dan luas saja.

Jenis-jenis Bangun Datar Bangun datar merupakan bidang yang dibatasi dengan garis dan tidak mempunyai ketebalan. Bangun datar terbagi menjadi beberapa jenis, adapun jenis-jenis bangun datar adalah sebagai berikut: 1) Persegi Bangun ini 
terbentuk oleh 4 buah rusuk yang sama panjang dan memiliki 4 buah sudut sikusiku.persegi memiliki sifat: Mempunyai 4 titik sudut. Mempunyai 4 sudut $90^{\circ}$. Mempunyai 2 diagonal yang sama panjang. Mempunyai 4 simetri lipat. Mempunyai 4 simetri putar, 2) Persegi Panjang Bangun ini terbentuk oleh dua pasang rusuk yang masing-masing sama panjang dan sejajar terhadap pasangannya, dan memiliki 4 buah sudut siku-siku. Persegi panjang memiliki sifat: Sisi yang berhadapan sama sejajar dan panjang. Sisi-sisi persegi panjang saling tegak lurus Mempunyai 4 sudut $90^{\circ}$. Mempunyai 2 diagonal yang sama panjang Mempunyai 2 simetri lipat, Mempunyai 2 simetri putar.

\section{Karakteristik Peserta Didik TK}

Setiap usia mempunyai tugas

perkembangan yang berbeda, misalnya pada usia 4 bulan pada umumnya anak bisa tengkurap, usia 6 bulan bisa duduk, 10 bulan bisa berdiri, dan 1 tahun bisa berjalan. Pada dasarnya semua anak memiliki pola perkembangan yang dapat diramalkan, misalnya anak akan bisa berjalan setelah bisa berdiri. Oleh karena itu pendidik harus memahami tahap perkembangan anak dan menyusun kegiatan sesuai dengan tahapan perkembangan untuk mendukung pencapaian tahap perkembangan yang lebih tinggi.

Sebagaimana pengertian diatas lebih lajut di ungkapkan oleh Mulyani S 2014; dalam perkembangan terdapat pertumbuhan, pola gerakan ini kompleks karena merupakan hasil ( produk) dari beberapa proses yaitu proses biologis, proses kognitif, dan proses sosial.

Karektristik Peserta Didik TK menurut Santrok dan Yusen dalam Modul UT, dalam Mulyani Sumantri;2014 fase kanak-kanak awal adalah fase perkembangaan yang berlangsun sejak akhir masa bayi samapai 5 atau 6 tahun, kadang-kadang disebut masa pra sekolah. Selamaa fase ini mereka belajar melakukan sendiri banyak dan berkembang keterampilan-keterampilan yangberkaitan dengan kesiapan untuk bersekolah dan memanfaatkan waktu selama beberapa jam untuk bermain sendidri ataupun dengan temannya. Pada fase ini kanak-kanak berusaha pula berlatih untuk terampil berbicara sehingga akaan didapati mereka melakukan monolog atau berbicara sendiri seolah-olah sedang berbicara dengan orang lain.

Berdasarkan paparan tersebut diaatas pada pase inilah yang kita kenal dengan fase anak memasuki taman kanak-kanak (TK)

\section{METODE PENELITIAN}

Desain penelitian yang dikembangan dalam penelitian ini adalah desain yang diadaptasi dari Kemmis dan Taggart (Suwarsih Madya, 2004: 20), yang menggambarkan bahwa penelitian tindakan kelas dilaksanaan melalui beberapa siklus dan masing-masing terdiri dari 4 tahap. Bagan model spiral Kemmis dan Taggart digambarkan sebagai berikut:
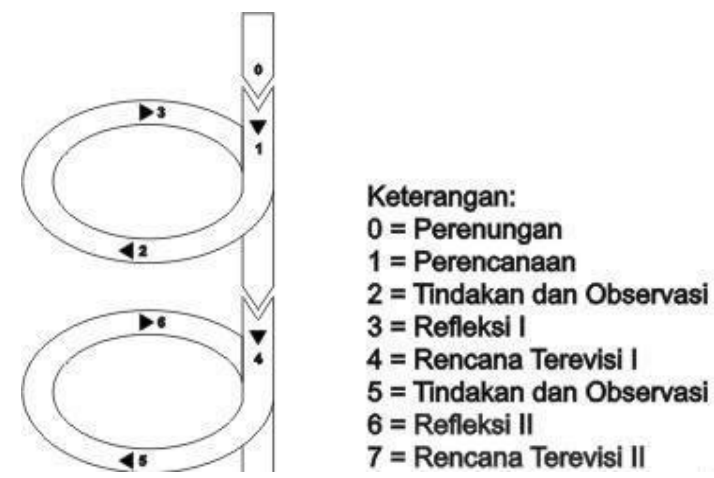

Gambar. Proses penelitian tindakan

Secara garis besar, penelitian tindakan kelas model Kemmis \& Taggart terdiri dari empat aspek pokok, yaitu: a) Penyusunan Rencana, b) Tindakan, c) Observasi, d) Refleksi

Tempat, Waktu, dan Subyek Penelitian

Penelitian ini dilakukan TK Islam An - Nur Beber Desa Pengenjek Kecamatan Jonggat Kabupaten Lombok Tengah yang terletak di di jalan BeberPengenjek. Penelitian tindakan kelas ini dilaksanakan pada semester ganjil tahun pelajaran 2018 /2019, dan Waktu pelaksanaan penelitian mulai dari bulan Juli sampai dengan September 2018, pelaksanaan tindakan sesuai dengan RPPH, pada siswa kelompok usia A yang berjumlah 20 orang terdiri dari 7 siswa laki - laki dan 13 siswa perempuan ,mereka berasal dari sekitar wilayah lingkungan sekolah.

\section{Teknik Pengumpulan Data}


Teknik pengumpulan data dalam penelitian ini adalah sebagai berikut: a) Observasi adalah suatu teknik yang dilakukan dengan cara mengadakan pengamatan secara teliti serta pencatatan secara sistematis, 2) tes Soal-soal kuis dibuat dalam bentuk gambar dan puzzle, 3) Dokumentasi digunakan untuk memperkuat data yang diperoleh dalam observasi.

\section{Instrumen Penelitian}

Menurut Suharsimi Arikunto (2006: 160), instrumen penelitian adalah suatu alat atau fasilitas yang digunakan dalam mengumpulkan data agar lebih mudah dan hasilnya lebih baik dalam arti lebih cermat, lengkap, dan sistematis, sehingga lebih mudah diolah. Untuk mengumpulkan data yang diperlukan dalam penelitian, digunakan beberapa teknik sebagai berikut: 1) Lembar observasi, 2) Soal Tes

\section{Teknik Analisis Data}

Teknik analisis data dalam penelitian ini dengan merefleksikan hasil observasi dari penerapan pembelajaran menggunakan media puzzle dalam meningkatkan keaktifan siswa, dan tes untuk mengetahui prestasi belajar siswa selama poses tindakan berlangsung.

.Metode analisis yang digunakan dalam penelitian ini adalah deskriptif kuantitatif . Deskriptif kuantitatif digunakan untuk menganalisis data berupa angka. Adapun rumus yang digunakan (Anas Sudjiono, 2010: 43):

$$
P=\frac{f}{N} \times 100 \%
$$

\section{Keterangan:}

$\mathrm{P}=$ Angka persentase

$\mathrm{f}=$ Frekuensi yang sedang dicari persentasenya

$\mathrm{N}=$ Number of Cases (Jumlah frekuensi/banyaknya individu)

\section{HASIL PENELITIAN DAN}

\section{PEMBAHASAN}

Siklus I

Penelitian ini terdiri dari dua siklus, dalam hal ini peneliti bertindak sebagai peneliti dan guru sebagai pengajar dengan menerapkan tindakan yang mengacu pada skenario pembelajaran, dan rencana pelaksanaan penelitian dilakukan pada tanggal 17 Juli 2018 dengan alokasi waktu 2x 35 menit dengan tema Diri Sendiri materi Mengenal Geometri Adapun langkah langkahnya sebagai berikut .

Pelaksanaan tindakan siklus I dilaksanakan pada tanggal 17 juli 2018 mulai pukul 07.50 WITA sampai dengan pukul 09.25 WITA. Dalam proses bembelajaran yang dilaksanakan, guru berperan langsung sebagai pengajar dan sekaligus sebagai peneliti dibantu seorang guru mitra kolaborasi sebagai pengamat proses dalam pembelajaran. Setelah siswa selesai mengerjakan LKS maka di katahu hasil belajarnya seperti yang tertera pada tabel dibawah ini.

Dari hasil analisa data dapat dilhat hasil belajar siswa Kelompok A TK Islam An - nur Beber pada siklus I ,memperoleh nilai rata - rata sebesar 66,7 dengan persentase ketuntasan $55 \%$ atau sebanyak 11 siswa tuntas belajar dan 9 siswa belum tuntas dengan persentase sebesar $45 \%$, dan ketuntasan klasikal yang dipatok juga belum tercapai dikarenakan Peserta Didik terlalu banyak main main dan guru kurang kontrol di dalam kelas, dan maka penelitian ini dilanjutkan kesiklus berikutnya.

\section{Siklus II}

Siklus II dilaksanakan pada tanggal 7 Agustus 2018, di Kelompok bermain TK Islam An - Nur Beber dengan jumlah peserta didik sebanyak 20 orang, langkah langkah yang dilakukan sama dengan siklus I hanya dengan menggunkan RPP yang sudah direvisi, langkah - langkah yang dilakukan sebagai berikut:

Pelaksanaan penelitian dilakukan sesuai dengan yang sudah tertuang dalam RPKH, yaitu mengadakan proses belajar mengajar dengan panduan RPKH, dan pada kegiatan akhir dilakukan evaluasi hasil belajar siswa siklus II seperti yang tertuang dalam tabel sebagai berikut :

Atas hasil analisa datat hasil belajar Peserta Didik Kelompok A TK Islam AnNur Beber pada siklus II dengan menggunakan keping geometri ,memperoleh 
nilai rata - rata sebesar 85,7, sebanyak 19 orang sudah tuntas belajar dengan persentase sebesar $95 \%$ dan siswa yang tidak tuntas sebanyak 1 orang dengan persentase $5 \%$. maka, ketuntasan klasikalpun sudah tercapai yaitu $\geq 80$. Hal ini terjadi karena guru mampu mengatasi kendala - kendala yang terjadi pada siklus I dan semua indikator yang diharapkan sudah tercapai , sehingga penelitian ini dihentikan sampai pada siklus II.

\section{Pembahasan Hasil Penelitian}

Berdasarkan data hasil belajar siswa siklus I dengan menggunakan media keping geometri pada Kelompok Bermain TK A Islam An - Nur Beber, terus menunjukkan peningkatan hasil belajar yang signifikan berdasarkan nilai yang diperoleh mulai dari siklus I menuju siklus II seperti data yang diperoleh sebagai berikut :

$$
\text { Hasil belajar siswa }
$$

Kelompok A TK Islam An - nur Beber pada siklus I dengan menggunakan media keping geometri , memperoleh nilai rata rata sebesar 66,7 dengan persentase ketuntasan $55 \%$ atau sebanyak 11 siswa tuntas belajar dan 9 siswa belum tuntas dengan persentase sebesar $45 \%$, dan ketuntasan klasikal yang dipatok juga belum tercapai dikarenakan Peserta Didik terlalu banyak main - main dan guru kurang kontrol di dalam kelas, dan maka penelitian ini dilanjutkan kesiklus berikutnya.

Sedangkan hasil belajar siswa kelompok TK Islam An-Nur Beber pada siklus II dengan menggunakan keping geometri, memperoleh nilai rata - rata sebesar 85,7, sebanyak 19 orang sudah tuntas belajar dengan persentase sebesar $95 \%$ dan siswa yang tidak tuntas sebanyak 1 orang dengan persentase $5 \%$. maka, ketuntasan klasikalpun sudah tercapai yaitu $\geq 80$. Hal ini terjadi karena guru mampu mengatasi kendala - kendala yang terjadi pada siklus I dan semua indikator yang diharapkan sudah tercapai , sehingga penelitian ini dihentikan sampai pada siklus II.

Jika melihat perbandingan kedua data tersebut maka dapat kita paparkan bahwa nilai rata - rata yang diperoleh pada siklus I sebesar 66,7 kemudian meningkat pada siklus I I menjadi nilai rata - rata diperoleh sebesar 85,7 terjadi peningkatan 19 poin, dan jumlah siswa yang tuntas pada siklus I sebanyak 11 orang atau dengan persentase ketuntasan sebesar $55 \%$, kemudian meningkat pada siklus II jumlah siswa yang tuntas sebanyak 19 orang dengan persentase sebesar $95 \%$, terjadi peningkatan sebesar 40 poin, begitu juga dengan ketuntasan klasikal yang dipersyaratkan $\geq 80$ $\%$ juga sudah terpenuhi , maka penelitian ini dihentikan sampai pada siklus II.

Dengan demikian dapat diambil kesimpulan bahwa dengan menggunakan media keping geometri dapat meningkatkan hasil belajar siswa Tema diri sendiri materi mengenal geometri pada Kelompok A TK Islam An-Nur Beber Kecamatan Jonggat Tahun pelajaran 2018 / 2019.

\section{KESIMPULAN}

Berdasarkan hasil penelitian tindakan kelas yang telah dilakukan di TK Islam An - Nur Beber kelompok usia A tahun pelajaran 2018 / 2019 yang dilaksanakan dari bulan Juli Sampai dengan September 2018. dengan subyek penelitian berjumlah 20 siswa terdiri dari 7 siswa laki- laki dan 13 orang siswa perempuan. Hasil belajar terus terjadi peningkatan dari siklus I ke siklus II berdasarkan perolehan nilai .

Jika melihat perbandingan kedua data tersebut maka dapat kita paparkan bahwa nilai rata - rata yang diperoleh pada siklus I sebesar 66,7 kemudian meningkat pada siklus I I menjadi nilai rata - rata diperoleh sebesar 85,7 terjadi peningkatan 19 poin, dan jumlah siswa yang tuntas pada siklus I sebanyak 11 orang atau dengan persentase ketuntasan sebesar 55\% , kemudian meningkat pada siklus II jumlah siswa yang tuntas sebanyak 19 orang dengan persentase sebesar $95 \%$, terjadi peningkatan sebesar 40 poin, begitu juga dengan ketuntasan klasikal yang dipersyaratkan $\geq 80$ $\%$ juga sudah terpenuhi, maka penelitian ini dihentikan sampai pada siklus II.

Dengan demikian dapat diambil kesimpulan bahwa dengan menggunakan media keping geometri dapat meningkatkan hasil belajar siswa tema Tanaman materi 
mengenal angka pada Kelompok A TK Islam An-Nur Beber Kecamatan Jonggat Tahun pelajaran 2018 / 2019.

\section{DAFTAR PUSTAKA}

Abdul Majid. 2006. Perencanaan Pembelajaran. Bandung: PT Remaja Rosdakarya. Branson Margaret DKK. 2009. Belajar Civic Education dari Amerika. Yogyakarta:LKiS.

Cholisin. 2004. Pendidikan Kewarganegaraan (Civic Education). Yogyakarta: Fakultas Ilmu sosial dan Ekonomi UNY.

Dimyati \& Mudjiono. 2002. Belajar dan Pembelajaran. Jakarta: Depdikbud dan PT Renika Cipta.

John Sweller. 2009. Instructional Design in Technical Areas. Australia: ACER.

Nana Sudjana. 2002. Penilaian Hasil Proses Belajar Mengajar. Bandung: PT Remaja Rosdakarya.

Ngalim Purwanto. 1993. Psikologi Pendidikan. Bandung: PT Remaja Rosdakarya. . 2000. Psikologi Pendidikan. Bandung: PT. Remaja Rosdakarya.

Rochiati Wiriaatmadja. (2005). Metode Penelitian Tindakan Kelas. Bandung: Pasca Sarjana UPI dan PT. Remaja Rosdakarya

Slameto. 2010. Belajar dan Fakto-faktor yang Mempengaruhinya. Jakarta: Rineka Cipta.

Sotikno Sobry.2004. Menuju Pendidikan Bermutu. Mataram: NTP Press

Sugiyono. 2011. Metode Penelitian Kuantitatif, Kualitatif, dan Kombinasi. Bandung: Alfabeta.

Suharsimi Arikunto. (2006). Dasar-dasar Evaluasi Pendidikan. Jakrta: Bumi Aksara. - 2008. Penelitian Tindakan Kelas. Jakarta: Raja Grafindo Persada.

Suryobroto. (2009). Psikologi Pendidikan. Jakarta: Raja Grafindo Persada.
Suwarsih Madya. (1994). Penduan Penelitian Tindakan. Lembaga Penelitian FKIP IKIP Yogyakarta

Syaiful Bahri Djamarah dan Aswan Zain.1997. Strategi Belajar Mengajar. Jakarta: Rineka Cipta. - 2010. Strategi Belajar Mengajar. Jakarta: Rineka Cipta.

S. Kemis and R. Mc Taggart. 2007. The Action Research Planner. Victoria: Deakin University Press.

W. Gulo. 2002. Strategi Belajar Mengajar. Jakarta: PT. Grasindo.

\begin{tabular}{llr} 
Winarno. & \multicolumn{1}{c}{ (2006). } & Pendidikan \\
& Kewarganegaraan. & Jakarta: \\
Bumi Aksara &
\end{tabular}

